\title{
Palbociclib Regimen
}

National Cancer Institute

\section{Source}

National Cancer Institute. Palbociclib Regimen. NCI Thesaurus. Code C160808.

A regimen consisting of palbociclib that may be used in the treatment of advanced or metastatic human epidermal growth factor receptor 2 (HER2)-negative, hormone receptor (HR)-positive breast cancer. 